\title{
Journal of Dairy Science Silage Special Issue: Introduction
}

\author{
Richard J. Grant ${ }^{* 1,2}$ and Adegbola T. Adesogan† \\ *William H. Miner Agricultural Research Institute, Chazy, NY 12921 \\ †Department of Animal Sciences, University of Florida, Gainesville 32611
}

Silage has been defined as the fermented and acidic stored feed from agricultural crops (Wilkinson et al., 2003). Silages are routinely fed on dairy and livestock farms worldwide because they minimize the loss of nutrients from harvest through storage and, when compared with dry forage, facilitate timely and efficient feed mixing and handling on-farm (Mahanna and Chase, 2003), and require less wilting. With ensiling, large amounts of forage can be conserved rapidly, and the harvesting and storing process is less dependent on the weather than haymaking. Commonly ensiled crops include corn, alfalfa and other legumes, grasses, sorghum, and other alternative crops.

In the United States, the importance of silage in animal feeding systems is exemplified by the growth in corn silage as a forage crop. Between 1982 and 2012, corn silage production increased by approximately $33 \%$ (Martin et al., 2017). Currently, 2.61 million hectares are used for corn silage production, with yields of nearly $44 \mathrm{Mg} /$ ha (20 tons/acre; USDA-NASS, 2017).

Thoma et al. (2013) derived an average US dairy ration from 350 farm survey results. The feed ingredient profile indicated that 10 forages comprised over half of the ration DM. Corn and alfalfa silage together accounted for over one-third of the dietary DM, with the remainder provided by wheat silage, sorghum silage, and oat silage, along with some dry hay and pasture.

Clearly, silages provide the forage base for many dairy feeding systems. Silages supply energy, protein, and digestible fiber to ruminant diets and the ensiling process will have substantial effects on the nutritive value of the silage. Increasingly, silage crop management will reflect a balance between nutrient supply to the animal and environmental needs to optimize nutrient cycling on farms (Martin et al., 2017).

Proper silage management is critical because significant amounts of DM are lost during silage making due to mechanical damage during harvesting, plant and microbial respiration, deamination and proteoly-

Received February 22, 2018.

Accepted February 23, 2018.

${ }^{1}$ Corresponding author: grant@whminer.com

${ }^{2}$ Guest editor, Journal of Dairy Science Silage Special Issue. sis, seepage, aerobic spoilage, and feed-out processes. These losses often result in reductions in the energy value and nutritional quality of silage. Average DM losses during silage production are 14 to $24 \%$ (Rotz and Muck, 1994), although losses exceeding 30\% may occur in poorly managed silages. Based on a $20 \%$ DM loss estimate, a $\$ 50 /$ ton price, and production of 116.5 million megagrams (128.4 million tons) of corn silage in 2017 (USDA-NASS, 2017), the economic impact of corn silage DM losses alone is about $\$ 1.284$ billion/yr. For all silage types, the estimate exceeds $\$ 2$ billion/yr (Rotz and Muck, 1994), and this hidden cost represents a loss of potentially useful nutrients that are vital for optimizing the profitability of dairy farms.

A landmark publication in the biology and management of silage making, storing, and feeding was Silage Science and Technology (Agronomy Monograph 42; Buxton et al., 2003). This 19-chapter comprehensive review included silage microbiology; assessing silage quality; pre- and post-harvest factors that influence silage quality; use of silage additives; harvesting, feeding, and storing silage; and chapters specific to different silage types such as legumes, grasses, corn silage, and other silage alternatives. This monograph has essentially served as the definitive resource for researchers, students, and allied industry professionals interested in silage management.

The primary goal of this Silage Special Issue in the Journal of Dairy Science is to summarize and interpret the considerable research progress over the past $15 \mathrm{yr}$ and to review important silage topics not included in Agronomy Monograph 42: Silage Science and Technology. Topics such as silage inoculants and additives are brought up to date with an emphasis on research conducted since 2003. In the Journal of Dairy Science alone, nearly 30 articles with the words "silage inoculant" or "additive" in the title have been published in the past $10 \mathrm{yr}$. A related topic that was largely absent from the monograph was molecular approaches to define silage microbial ecology. This burgeoning field of research promises substantial breakthroughs in silage technology and is thoroughly reviewed in this issue.

The article on silage harvesting technology takes a futuristic look at what technology will likely be used 
to harvest and ensile silages in the coming years. Likewise, silage characterization now extends beyond traditional measures such as $\mathrm{pH}, \mathrm{VFA}$, lactic acid, and carbohydrate and protein fractions to include components of more recent interest such as volatile organic compounds. Silages can emit large amounts of these volatile organic compounds, which are precursors in the formation of atmospheric ozone (Bonifacio et al., 2017). The environmental consequences of silage feeding and management have become a primary societal concern (Martin et al., 2017).

Another important area that has not been intensively reviewed recently are silage-related animal and human health concerns such as mycotoxins, and hazards associated with poor silage fermentations and food-borne pathogens. Mycotoxins are a recurring issue in livestock feeding, and the chapter in this Silage Special Issue incorporates research advances made in the past decade on their occurrence, effects, and mitigation. Poorly made or contaminated silage can be a source of pathogenic bacteria or various hazardous compounds that may compromise dairy cow performance, lessen the safety and quality dairy products, and negatively affect animal and human health (Driehuis, 2013).

The article on DM and quality losses in silage updates the information in Silage Science and Technology and the review of Rotz and Muck (1994) on this topic by focusing on research published since 2003 that highlights factors that predispose silage to such losses and effective mitigation strategies.

The silage feeding management article summarizes recent research on the interaction between silage physicochemical properties and feed bunk management that is important for competitively fed cows. Increasingly, research shows that factors inherent in the silage and feeding environment will interact to determine DMI and cow productivity.

Rather than separate papers on individual silage types, which were done so well in Silage Science and Technology, this Silage Special Issue focuses on silage management in hot and cold environments across a wide range of silage types.

The paper on baleage outlines differences between forages preserved with this technique versus other forage preservation techniques. It also describes recent technologies and management strategies for optimizing the quality of this form of silage, which is increasingly popular among small and mid-sized dairy and beef producers.

Finally, silage safety considerations are included in this special issue. This topic has rarely appeared in a peer-reviewed scientific publication, but there is no more important topic for those engaged in silage making and management due to the risks posed to human life.

This Silage Special Issue is intended as a comprehensive, contemporary review of the major aspects of silage technology from harvest to feeding. It builds on the legacy of the Agronomy Monograph No. 42 (Silage Science and Technology) published in 2003. Together, these two references should serve as a complete resource for anyone interested in the science and management of silages.

\section{REFERENCES}

Bonifacio, H. F., C. A. Rotz, S. D. Hafner, F. Montes, M. Cohen, and F. M. Mitloehner. 2017. A process-based emission model of volatile organic compounds from silage sources in farms. Atmos. Environ. 152:85-97.

Buxton, D. R., R. E. Muck, and J. H. Harrison, ed. 2003. Silage Science and Technology. Agronomy Monograph No. 42. Am. Soc. Agron., Crop Sci. Soc. Am., Soil Sci. Soc. Am., Madison, WI.

Driehuis, F. 2013. Silage and the safety and quality of dairy foods: A review. Agric. Food Sci. 22:16-34.

Mahanna, W., and L. E. Chase. 2003. Practical applications and solutions to silage problems. Pages 855-895 in Silage Science and Technology. Agronomy Monograph No. 42. Am. Soc. Agron., Crop Sci. Soc. Am., Soil Sci. Soc. Am., Madison, WI.

Martin, N. P., M. P. Russelle, J. M. Powell, C. J. Sniffen, S. I. Smith, J. M. Tricarico, and R. J. Grant. 2017. Invited review: Sustainable forage and grain crop production for the US dairy industry. J. Dairy Sci. 100:9479-9494.

Rotz, C. A., and R. E. Muck. 1994. Changes in forage quality during harvest and storage. Pages 828-868 in Forage Quality, Evaluation and Utilization. G. Fahey, ed. Am. Soc. Agron. and Crop Sci. Soc. Am., Madison, WI.

Thoma, G., J. Popp, D. Shonnard, D. Nutter, M. Matlock, R. Ulrich, W. Kellogg, D. Soo Kim, Z. Heiderman, N. Kemper, F. Adom, and C. East. 2013. Regional analysis of greenhouse gas emissions from USA dairy farms: A cradle to farm-gate assessment of the American dairy industry circa 2008. Int. Dairy J. 21:S29-S40.

USDA-NASS. 2017. Statistics by subject: National Statistics for corn. Accessed Feb. 17, 2018. https://www.nass.usda.gov/Statistics_by _Subject/result.php?8BB999CB-9D36-333E-8266-6E39D3F9261F \&sector $=$ CROPS\&group $=$ FIELD $\% 20 \mathrm{CROPS} \&$ comm $=$ CORN .

Wilkinson, J. M., K. K. Bolsen, and C. J. Lin. 2003. History of silage. Pages 1-30 in Silage Science and Technology. Agronomy Monograph No. 42. Am. Soc. Agron., Crop Sci. Soc. Am., Soil Sci. Soc. Am., Madison, WI. 